\title{
PAYUNG HUKUM PENYANDANG DISABILITAS DALAM KONTEKS DUKUNGAN DAN AKSESIBILITAS TERHADAP PEMBANGUNAN SOSIAL BERKELANJUTAN
}

\author{
Oleh: \\ Muhammad Ramadhana Alfaris ${ }^{1}$
}

\begin{abstract}
Disability is a condition experienced by a person with various kinds of physical limitations. The thing of unfair is a sensitive part for people with disabilities, starting from discrimination, less of support, community stigma, and many inadequate access for people with disabilities. Therefore, the identification of problems in this study discusses the legal umbrella for persons with disabilities as well as support and accessibility to sustainable social development. This study uses descriptive analytical methods to explain the existing situation by using a normative juridical approach to identify and examine the law. The result is there are still many discriminatory attitudes towards persons with disabilities, such as from education access that is not yet the totality of persons with disabilities, then economic access for people with disabilities is less considered, then in health access that is still not fulfilled, especially health against physical disabilities, and less education of political access access for people with disabilities.
\end{abstract}

Kata Kunci: payung hukum disabilitas, dukungan, aksesibilitas, pembangunan sosial.

\section{PENDAHULUAN}

Kaum penyandang cacat atau disabilitas seharusnya memiliki perlakuan yang sama dan layak didapatkan demi menunjang kehidupannya. Tercerminkan pada Pancasila sila ke 5 yakni "keadilan sosial bagi seluruh rakyat Indonesia". Sila tersebut merupakan sebuah simbol, kode, dan juga teguran keras kepada rakyat Indonesia untuk dapat mewujudkan sebuah keadilan kepada setiap manusia pada umunya dan khususnya seluruh rakyat di Indonesia dengan berbagai macam landasan yang fundamental untuk menopang keadilan tersebut. hal yang sangat fundamental dalam aspek kehidupan manusia adalah Ketuhanan dengan asumsi bahwa manusia sama di mata Tuhan (secara teologi) dalam konteks kedudukan kodrati, hak, dan kewajiban. Lepas daripada itu perbedaan terjadi ketika sudah masuk ke ranah hubungan sosial sesama manusia, bahkan mirisnya adalah sampai terjadi diskriminatif yang cukup signifikan.

Pasalnya, sebagian besar dari penyandang cacat tersebut menyadari betul akan kebutuhan-kebutuhan pokok yang harus dipenuhi untuk tetap bertahan hidup dengan cara apapun seperti, bekerja keras sesuai dengan kemampuannya meskipun mereka memiliki keterbatasan fisik. Kendati demikian, hanya salah satu bagian atau organ tubuh saja yang terbatas, tetapi masih ada bagian-bagian lain yang masih berfungsi dengan baik dan bisa dioptimalkan guna

${ }^{1}$ Fakultas Hukum, Universitas Widyagama Malang 
memenuhi kebutuhan untuk bertahan hidup. Berangkat dari hal tersebut, untuk menghadapi dinamika kehidupan di luar, para kaum penyandang cacat sangat membutuhkan banyak dukungan, mulai dari dukungan dari aktor sosial terdekat yakni keluarga, kemudian lungkungan, dan masyarakat sekitar dalam rangka memotivasi kemandirian eknominya $^{2}$. Menurut (Hurlock, 2004), kondisi yang dialami oleh para penyandang cacat atau disabilitas secara fisik menyebabkan mereka sangat sulit untuk melakukan segala aktivitas. Hal tersebut cukup berpengaruh terhadap kehidupan mereka sehingga para penyandang cacat tersebut cenderung merasa lebih rendah dan berasumsi dirinya kurang beruntung, tidak memiliki pengetahuan (stock of knowledge), potensi diri, kemudian tidak dapat hidup mandiri, dan berpikiran tidak mampu mencapai apa yang mereka cita-citakan untuk masa depan

Dewasa ini, Masih Banyak terjadi peristiwa diskriminatif terhadap kaum difabel atau para penyandang cacat tersebut. Seperti yang telah dilansir di beberapa media bahwa di tahun 2014 menurut catatan Ombudsman, dari 62 perguruan tinggi negeri, 42 di antaranya menetapkan persyaratan yang mendiskriminasikan penyandang cacat, sedangkan 20 universitas lainnya tidak. Dari berita yang dilansir tersebut, menunjukkan bahwa masih terjadi sikap diskriminatif terhadap kaum penyandang cacat. Selanjutnya, di tahun 2017 terdapat sekelompok mahasiswa dari Fakultas Ilmu Komputer di slah satu Universitas di Indonesia telah melakukan perundungan (bullying) kepada seorang mahasiswa disabilitas. Bahkan peristiwa bullying tersebut sampai dipertontonkan kepada publik. Hal tersebut sungguh sangat memprihatinkan dan

\footnotetext{
2 Disarikan Muhammad Ramadhana Alfaris. 2017.
} Dukungan Sosial dan Aksesbilitas Pendidikan Inklusi menjadi indikator atas terjadinya degradasi bidang pendidikan serta degradasi aksesibilitas bagi penyandang cacat tersebut.

Senada dengan hal tersebut, dalam aspek pendidikan dewasa ini masih banyak yang belum menitikberatkan terhadap faktor aksesibilitas fisik khususnya bagi penyandang cacat atau disabilitas. Penanganan pendidikan tersebut lebih intens fokus kepada penanganan konten pendidikannya saja, kemudian program-program yang ada kerap terlihat pada penanganan non fisik seperti, proses pembelajaran, kurikulum, serta penilaian. Dalam artian masih jarang sekali lembaga pendidikan khususnya Perguruan Tinggi yang menerapkan aksesibilitas bagi penyandang cacat atau disabilitas yang berorientasi masa depan, jadi tidak sebatas mengenyam pendidikan saja, melainkan ketika sudah menyelesaikan studi di Perguruan Tinggi tetap mendapatkan aksesibilitas pekerjaan sesuai dengan potensi yang mereka miliki.

Berangkat dari hal tersebut, mengingat pentingnya pembangunan social di Indonesia, oleh karenanya memberikan sebuah inspirasi bagi penulis untuk memberikan gambaran dan ulasan bagaimana aspek hukum bagi penyandang disabilitas? Dukungan dan aksesibilitas terhadap pembangunan sosial berkelanjutan? Dengan tujuan tulisan ini dapat menambah kajian pustaka keilmuan.

\section{METODE}

Penelitian ini menggunakan metode penelitian deskriptif kualitatif bertujuan untuk mengungkapkan fenomena yang tidak dapat dikuantifikasikan yang bersifat deskriptif seperti proses suatu langkah kerja, formula suatu resep, pengertian-pengertian tentang suatu konsep yang beragam, karakteristik suatu barang dan jasa, gambargambar, gayagaya, tata cara suatu budaya, model fisik suatu

Di Perguruan Tinggi Berorientasi Masa Depan dan Kontinuitas. Prosiding Praktik Pendidikan Bagi Penyandang Disabilitas. hlm. 96 
artifak dan lain sebagainya ${ }^{3}$. Selain itu, dalam Sugiono (2012: 9) juga mengemukakan bahwa penelitian kualitatif sebagai metode penelitian yang berlandaskan pada filsafat postpositivisme yang digunakan untuk meneliti pada kondisi objek alamiah, di mana peneliti adalah sebagai instrumen kunci. Kemudian teknik pengumpulan data ada penelitian ini mengunakan triangulasi, analisis data bersifat induktif atau kualitatif, dan hasil penelitian kualitatif lebih menekankan makna daripada generalisasi.

Penelitian kualitatif memiliki lima macam karakter yaitu ${ }^{4}$ :

1. Mempunyai setting yang alamiah.

2. Data yang dikumpulkan dalam bentuk kalimat, gambar dan lainnya yang berisi deskripsi, transkrip, interview, catatan di kancah penelitian dan lain-lain.

3. Peneliti-peneliti kualitatif lebih mementingkan proses dari pada hasil.

4. Penelitian kualitatif mamentingkan makna, ini berarti peneliti berusaha memahami makna fenomena yang sedang diteliti.

Selain metode penelitian kualitatif, dalam penelitian ini juga menggunakan pendekatan yuridis normatif, yakni guna mengidentifikasi dan menelaah hukum melalui teori, konsep, asas hukum serta peraturan perundang-undangan yang berhubungan dengan penelitian Aspek Hukum Penyandang Disabilitas Dalam Konteks Dukungan dan Aksesibilitas Terhadap Pembangunan Sosial Berkelanjutan.

\section{HASIL DAN PEMBAHASAN}

\section{Aspek Hukum Penyandang Disabilitas}

Dalam UUD 1945 pasal 31 ayat (1) menegaskan bahwa setiap warga Negara berhak mendapatkan pendidikan yang layak. Undang-Undang tersebut menyatakan setiap warga Negara, jika merefleksikan kembali maka para kaum penyandang cacat merupakan warga Negara Indonesia dengan bentuk apapun kondisi fisik yang mana

\footnotetext{
${ }^{3}$ Dalam Aan Komariah, Djam'an Satori, 2011, hlm. 23

${ }^{4}$ Dalam buku Sugiyono,2007, hlm. 15
}

masing-masing dari mereka memiliki hak serta kewajiban yang sama dengan warga Negara Indonesia lainnya.

Kemudian Pasal 28 butir A-J yang mengatur tentang hak asasi manusia, dalam hal ini berimplikasi bagi penyandang disabilitas. Hak-hak bagi setiap warga negara juga sudah diatur di dalam Peraturan Perundang-undangan terutama dalam UU Dasar 1945 dimana dalam UU tersebut tidak membatasi seseorang yang mempunyai keterbatasan fisik dan/atau intelektual untuk mendapatkan hak. Senada dengan hal tersebut, dalam Konvensi Hak-Hak Penyandang Disabilitas diuraikan secara jelas mengenai hak-hak penyandang disabilitas, antara lain ${ }^{5}$ :

1. Hak untuk mendapat persamaan dan non-diskriminasi

2. Hak untuk mendapat pelayanan atau aksesibilitas

3. Hak atas kebebasan dan keamanan

4. Hak untuk mendapatkan pengakuan atas persamaan di muka hukum

5. Hak untuk mendapat keadilan

6. Hak bebas dari penyiksaan atau penghukuman yang kejam

7. Hak bebas dari eksploitasi dan kekerasan

8. Hak atas pendidikan dan kesehatan

9. Hak atas pekerjaan dan lapangan kerja

10. Hak kebebasan bergerak dan berkewarganegaraan

Hak-hak yang terdapat dalam Konvensi tersebut merupakan dasar bagi penyandang disabilitas untuk mempertahankan hidup serta memperjuangkan hak yang melekat pada dirinya. Dalam Konvensi ini penyandang disabilitas dilindungi oleh hukum untuk selalu berkembang dan dinamis dalam pembangunan social dan semua orang berhak untuk berpartisipasi, berkontribusi dan menikmati pembangunan ekonomi, sosial, budaya dan politik.

Berangkat dari hal tersebut, dalam UU RI sudah diatur dengan jelas ketentuan-ketentuan

${ }^{5}$ Dalam Makalah Maria Nurma. 2016. Perlindungan Hukum Dari Diskriminasi Bagi Penyandang Disabilitas Dalam Dunia Kerja. hlm. 2 
dalam meningkatkan kesjahteraan bagi penyandang cacat, seperti yang termaktub dalam UU RI No. 4 Tahun 1997 pasal 6 menegaskan tentang harus diberikan haknya kepada penyandang cacat berupa pendidikan, pekerjaan, perlakuan, aksesibilitas, rehabilitas, dan mengembangkan potensi, yang mana semua hal tersebut harus intens diperhatikkan guna menumbuhkembangkan sumber daya manusia yang berkualitas.

Jika menilik Undang-Undang RI No. 28 tahun 2002 tentang bangunan gedung, kemdian ditegaskan dalam pasal 27 ayat (1) yang meliputi tersedianya fasilitas dan aksesibilitas yang mudah, aman, dan nyaman termasuk bagi penyandang cacat dan lanjut usia. Lembaga pendidikan khususnya Perguruan Tinggi berimplikasi ke dalam kategori fasilitas umum yang seyogianya dapat mengakomodir aksesibilitas bagi penyandang cacat atau disabilitas tersebut. Kemudian pada pasal 14 berisikan perusahaan negara dan swasta memberikan kesempatan dan perlakuan yang sama kepada penyandang cacat dengan mempekerjakan penyandang cacat di perusahaannya sesuai dengan jenis dan derajat kecacatan, pendidikan, dan kemampuannya, yang jumlahnya disesuaikan dengan jumlah karyawan dan/atau kualifikasi perusahaan.

UU Nomor 8 Tahun 2016 Tentang Penyandang Disabilitas, pemerintah baik itu BUMN ataupun BUMD diwajibkan untuk mempekerjakan penyandang disabilitas paling sedikit $2 \%$ dari jumlah pegawai. Sementara perusahaan swasta diwajibkan mempekerjakan penyandang disabilitas paling sedikit $1 \%$ dari jumlah pekerja. Artinya penyandang disabilitas bisa diterima sebagai karyawan disesuaikan dengan kemampuannya.

Dalam Naskah Akademik Rancangan Undang-Undang Penyandang Disabilitas, Pemerintah

\footnotetext{
${ }^{6}$ Naskah Akademik RUU Penyandang Disabilitas, Agustus 2015, dalam Supriyadi Widodo Eddyono. 2015. Aspek-aspek Criminal Justice Bagi Penyandang Disabilitas. Jakarta: Institute for Criminal Justice Reform, hlm. 16
}

mengemukakan bahwa pemicu utama terjadinya marjinalisasi dan diskriminasi terhadap kaum penyandang disabilitas secara spesifik bermula dari mewabahnya sikap dan perilaku stereotip

dan prejudisme mulai dari kalangan awam hingga kelompok intelektual bahkan sampai kepada para elit kekuasaan. Oleh karenanya, urgensi reformasi hukum dalam bidang disabilitas tersebut didasarkan pada empat alasan utama, yaitu sebagai berikut ${ }^{6}$ :
a. Adanya Perubahan Cara Pandang
b. Adanya Perkembangan Lingkup Ragam Disabilitas
c. Kelompok Disabilitas Masih Kerap Mendapat Diskriminasi
d. Indonesia Telah Meratifikasi CRPD

Sedangkan ruang lingkup yang diatur dalam Rancangan Undang-Undang Penyandang Disabilitas, meliputi:

a. Perencanaan, Koordinasi, Monitoring,
dan Evaluasi Nasional
b. Keadilan dan Perlindungan Hukum
c. Pendidikan
d. Kebebasan Berekspresi, Komunikasi
dan Informasi
e. Komite Nasional Disabilitas Indonesia (KNDI)

f. Konsesi

g. Kartu Penyandang Disabilitas

h. Pendataan

i. Habilitasi dan Rehabilitasi

j. Sanksi

Dalam UU Tahun 2014 No. 18 mengenai Kesehatan Jiwa terdapat ketentuan mengenai pemeriksaan kesehatan jiwa seseorang yang diduga sebagai Orang Dengan Gangguan jiwa. Dalam UU Kesehatan Jiwa ini ditentukan upaya kesehatan jiwa berupa upaya rehabilitatif dan upaya kuratif dalam kerangka serangkaian kegiatan pelayanan Kesehatan Jiwa yang ditujukan untuk mencegah atau mengendalikan disabilitas ${ }^{7}$.

\footnotetext{
${ }^{7}$ Undang-Undang No. 18 Tahun 2014, Kesehatan

Jiwa, Pasal 18 huruf c dan Pasal 25 huruf a
} 
Berangkat dari hal tersebut, selain berbicara mengenai kesehatan jiwa, kesehatan jasmani secara komprehensif juga merupakan hal yang sangat penting. Seperti dalam Undang-Undang Nomor 36 Tahun 2009 tentang Kesehatan, yang memberikan banyak hak kepada semua warga negara Indonesia tentang hak-hak kesehatannya yang diatur di dalam Pasal 4 sampai Pasal 8. Hak-hak tersebut, antara lain:

1. Hak untuk memperoleh akses atas sumber daya di bidang kesehatan,

2. Hak memperoleh pelayanan kesehatan yang aman, bermutu dan terjangkau,

3. Hak untuk menentukan sendiri pelayanan kesehatan yang diperlukan bagi dirinya, mendapatkan lingkungan yang sehat bagi pencapaian derajat kesehatan, mendapatkan informasi dan edukasi tentang kesehatan yang seimbang dan bertanggung jawab.

\section{Dukungan dan Aksesibilitas Dalam Konteks Pembangunan Sosial}

Dukungan sosial merupakan suatu hal yang sangat mendasar dan diperlukan oleh setiap manusia khsusnya bagi penyandang cacat atau disabilitas guna meningkatkan mentalitas diri untuk tetap semangat dalam menjalani kehidupan. Menurut Baron \& Byme, dukungan sosial ialah sebuah kenyamanan fisik dan non-fisik yang diberikan oleh orang lain. Dalam artian, dukungan sosial yang sering dirasakan oleh masing-masing individu dapat diterima oleh banyak pihak, baik secara sadar maupun secara tidak sadar yang dilakukan oleh pemberi dukungan tersebut. Sedangkan menurut Sarafino, dukungan sosial merujuk pada suatu hal kenyamanan, penghargaan, kepedulian, atau bantuan yang sejatinya dirasakan oleh masing-masing individu dari orang lain atau kelompok.

Kebutuhan utama yang dibutuhkan oleh para penyandang cacat ini adalah dukungan secara moral terlebih dahulu untuk memantapkan keyakinan jiwa dan pikirannya agar tetap bersemangat dalam menjalani

\footnotetext{
${ }^{8}$ Muhammad Ramadhana Alfaris. 2017. op. cit., hlm. 98
}

kehidupan serta mencapai cita-cita yang mereka inginkan. Tentu saja dukungandukungan tersebut membutuhkan proses dari sumber yang jelas. Sumber-sumber dukungan menurut Cohen, dkk, bisa dimulai dan diimplementasikan dari pasangan, keluarga, tetangga, teman, rekan kerja, perawat, notabene tenaga ahli kesehatan ataupun kesejahteraan. Dalam artian, seluruh aktor sosial yang berada di sekitar penyandang cacat tersebut turut ikut andil dalam memberikan dukungan terhadap mereka.

Konteks tenaga ahli dari paparan di atas meliputi pihak civitas akademik yang mengambil peran dalam rangka memberikan dukungan dalam aspek pendidikan guna menumbuhkembangkan intelektual dan potensi yang ada pada para penyandang cacat tersebut, seperti upaya mempublikasikan kepada khalayak banyak bahwa Perguruan Tinggi selalu terbuka dan memiliki layanan akademik untuk para penyandang cacat atau disabilitas. Kemudian memiliki sarana dan prasarana guna mendukung peningkatan kualitas akademik yang inovatif mencakup di dalamnya pendidikan inklusi.

Bentuk-bentuk dukungan sosial yang diberikan kepada para penyandang cacat tersebut terdapat empat bentuk (Cohen, 1985:95) $)^{8}$ :

1. Dukungan yang berupa bantuan nyata (tangible support),

Bantuan nyata dalam hal ini ialah sebuah dukungan nyata yang bersifat materil seperti, bantuan tenaga, uang, waktu, dan bantuan lain yang realistis.

2. Dukungan dalam penilaian atau penghargaan (appraisal support), Dukungan secara penghargaan pun dilakukan dalam bentuk penghargaan positif secara ekspresif terhadap individu agar dapat mempertahankan keyakinannya. 
3. Dukungan diri sendiri (self-esteern support),

Dukungan diri sendiri masuk ke ranah emosi dalam perspektif eksistensi diri di mana menjaga keadaan emosi dan ekspresi tetap stabil untuk menumbuhkan karakter positif dan optimistis bagi para penyandang cacat atau disabilitas tersebut.
4. Dukungan menjadi bagian dari kelompok dan memiliki afeksi kebersamaan (belonging support), Dukungan kebersamaan terhadap mereka para penyandang cacat, dalam hal ini semua lapisan masyarakat merangkul atas eksistensi mereka dan tidak ada diskriminatif. Dalam artian partisipasi masyarakat memiliki peran untuk memberikan dukungan secara lektif bagi penyandang disabilitas.

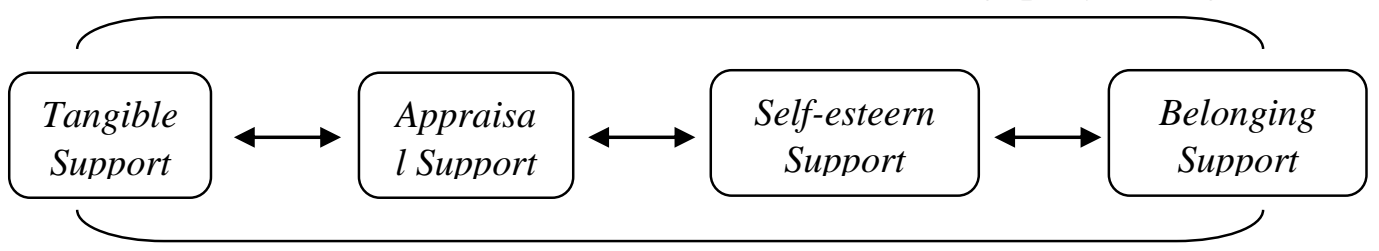

Keempat bentuk dukungan sosial tersebut tidak dapat dipisahkan, dalam artian masing-masing bentuk saling berkaitan satu dengan yang lainnya.

\section{Akses Pendidikan}

Aksesibilitas merupakan hal yang penting dalam penyelenggaraan pendidikan inklusi di Perguruan Tinggi. Akses memiliki arti suatu hal yang dapat dikaitkan dan dijadikan akses dapat dikatakan bagian dari proses penyelenggaraan pendidikan inklusi di Perguruan Tinggi. Akses yang baik dapat ditentukan dari kualitas sumber daya manusia. Dalam artian, ketika sumber daya manusianya sangat baik, maka degnan sendirinya akan menciptakan peluang mendapatkan akses yang lebih baik, begitupun sebaliknya. Jadi ketika memiliki sebuah prestasi maka secara otomatis akan mendatangkan sebuah prestis. Dapat dikategorikan sebagai pencapaian kepuasan kinerja yang maksimal dalam implementasinya terhadap pendidikan inklusi.

Senada dengan hal tersebut, Akses dalam bentuk fisik yang sekiranya dapat menunjang pendidikan inklusi di Perguruan Tinggi ialah tersedianya sarana dan prasarana yang sangat memadai diberbagai sektor kehidupan baik di sektor kesejahteraan sosial, sektor kesehatan, sektor pendidikan, dan fasilitas umum lainnya untuk melengkapi pendidikan inklusi di Perguruan Tinggi. Di samping itu, akses dalam bentuk non-fisik seperti ketersediaan kesempatan menempuh pendidikan yang lebih tinggi, terdapat peluang memporeleh pekerjaan yang layak dan sepadan dengan kompetensi, dan terciptanya lingkungan yang aman.

Secara umum mengenai aksesibilitas di Perguruan Tinggi yang diperuntukkan bagi penyandang cacat atau disabilitas menurut fungsinya dikategorikan ke dalam dua jenis yakni,

1. Fasilitas-fasilitas yang dapat digunakan oleh siapa saja, dalam artian tidak hanya para penyandang cacat atau disabilitas yang dapat menggunakan fasilitas tersebut, seperti misalnya akses jalan, perpustakaan, ruang tunggu (bagi pengantar/perawat penyandang cacat atau disabilitas), public space, profesionalitas layanan akademik, ketersediaan tangga untuk gedung bertingkat atau lift, dan lain sebagainya yang bersifat umum untuk khalayak banayak.

2. Fasilitas-fasilitas yang khusus atau hanya dapat digunakan oleh penyandang cacat atau disabilitas saja, dalam artian orang yang tidak menyandang disabilitas tidak diperbolehkan menggunakan fasilitas tersebut, seperti misalnya WC (kamar 
mandi), dan lain sebagainya yang sekiranya khusus hanya untuk penyandang cacat atau disabilitas saja.

Pendidikan Tinggi pada dasarnya memberikan kesempatan kepada setiap manusia untuk berkembang sesuai dengan potensinya. Penyelenggaraan pendidikan inklusi di Perguruan Tinggi secara prosedural umum memiliki syarat bahwa bagi para penyandang cacat atau disabilitas yang memiliki persyaratan akademik dalam pendidikan maka mereka mempunyai hak untuk ikut berkompetisi dalam memperebutkan kursi kuliah di salah satu PerguruanTinggi. Selanjutnya, tidak ada batasan kepada penyandang cacat atau disabilitas dalam memilih dan menentukan program studi/jurusan yang terdapat di Perguruan Tinggi. Karena pada dasarnya pendidikan inklusi memberikan kebebasan dan keterbukaan bagi mereka penyandang cacat atau disabilitas untuk memilih dan menentukan program studi/jurusan yang diminati. Sejatinya, para penyandang disabilitas pun dapat dan akan mengukur dengan sendirinya atas situasi, kondisi, dan kemampuannya. Misalkan ada seorang tunadaksa yang hanya memiliki satu kaki dan sangat berminat menjadi seorang programer di bidang IT, maka seorang tunadaksa tersebut dipersilahkan memilih program studi di ilmu komputer.

Aksesibilitas yang diberikan kepada para penyandang cacat atau disabilitas tersebut dapat dikatakan tidak hanya putus sampai di jenjang pendidikan saja, akan tetapi berorientasi masa depan. Berorientasi masa depan di sini dapat diibaratkan seperti proses mengalirnya dari hulu ke hilir. Mulai dari dukungan kemudian aksesibilitas dalam pendidikan serta mendapatkan pekerjaan yang layak dan ditinjau dari perspektif teoritis dan praktisnya. Jadi, penyelenggara pendidikan inklusi seperti Perguruan Tinggi seyogianya dapat bekerjasama dan membangun jaringan dengan satuan lain misalnya, satuan organisasi profesi, lembaga rehabilitasi, lembaga kesehatan, lembaga kesejahteraan masyarakat, dunia usaha, lembaga swadaya masyarakat (LSM), dan masyarakat.

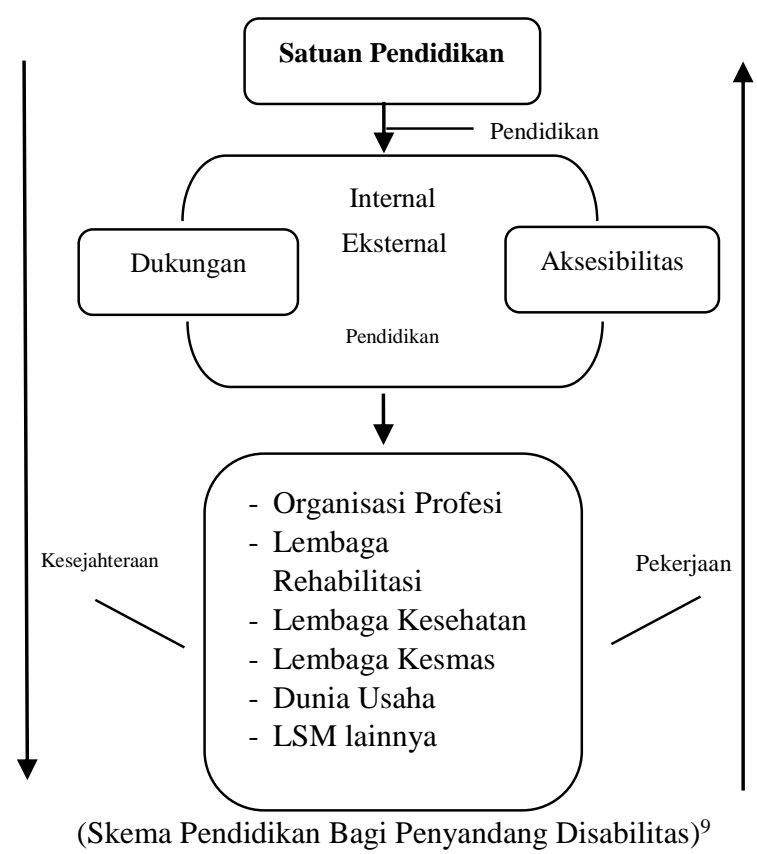

Skema di atas merupakan bagan alur dalam pengimplementasian pendidikan inklusi di Perguruan Tinggi. Dapat dikatakan, para penyandang cacat atau disabilitas mendapatkan dukungan dan aksesibilitas penuh untuk kehidupannya. Peran Perguruan Tinggi diasumsikan sebagai peran utama dalam penyelenggaraan pendidikan inklusi, di mana Perguruan Tinggi memberikan dukungan dan aksesibilitas penuh, kedua hal tersebut bersifat umum baik internal maupun eksternal. Konteks internal, dalam artian dukungan dari Perguruan Tinggi terkait yang diberikan penyandang cacat atau disabilitas. Dukungan internal bukan hanya berlaku bagi penyandang cacat saja, akan tetapi sosialisasi tentang anti-diskriminatif juga diberikan kepada peserta didik lainnya agar tidak terjadi sikap intoleran. Kemudian, eksternalnya merupakan dukungan dari keluarga, dan masyarakat sekitar yang pada intinya berada di luar Perguruan Tinggi. Bergitupun juga dalam konteks aksesbilitas, bisa dari internal yakni Perguruan Tinggi terkait dan eksternal dari aktor-aktor sosial di luar Perguruan

${ }^{9}$ Ibid. hlm. 101 
Tinggi. Selanjutnya Perguruan Tinggi membangun kerjasama dan jaraingan kepada organisasi, lembaga, LSM, dan Perusahaan untuk menyalurkan potensi atau bakat yang mereka peroleh setelah mengenyam pendidikan pendidikan formal di Perguruan Tinggi, yakni diberikan pekerjaan yang layak guna membantu roda perekonomian mereka.

Alur proses yang berkelanjutan adalah sebuah konsep dasar jangka panjang yang bersifat dinamis dan memanifestasikan sebuah terapan yang berkelanjutan sesuai dengan dinamika empirik. Berkelanjutan dalam hal ini merupakan sebuah paradigma dalam menciptakan wujud nyata dalam realita. Dalam pendidikan inklusi untuk para penyandang cacat atau disabilitas, konteks masa depan seyogianya menjadi target pembangunan, yakni membangun sistem pendidikan yang memikirkan masa depan bagi peserta didik pada umumnya dan penyandang cacat pada khususnya untuk tetap produktif dan efektif. Sedangkan kontinuitas merupakan indikator dalam implementasi dari masa depan yang terus-menerus diwujudkan agar tidak terjadi suatu hal yang bersifat kontemporer semata dan stagnan.

\section{Akses Ekonomi.}

Dalam aspek ekonomi menjadi hal yang dilematis. Di satu sisi dianggap sebagai beban sementara di sisi lain mereka dibatasi dan tidak didukung secara maksimal. Penetapan syarat sehat jasmani dan rohani dalam perekrutan dan pemberlakuan tenaga kerja menjadi hambatan utamanya. Tenaga kerja dianggap tidak sehat bila menggunakan tongkat, kaca mata hitam atau kursi roda. Keterampilan yang miliki menjadi sia-sia ketika diperhadapkan pada syarat sehat jasmani dan rohani yang batasannyapun tidak begitu jelas. Sementara di segi lain, berbagai survey dan laporan statistik mengelompokkan sebagai golongan tak berpenghasilan dan warga miskin yang membebani secara ekonomi.

Aspek ekonomi mrupakan hal yang tidak kalah penting untuk masyarakat pada umumnya dan khususnya bagi para penyandang cacat atau disabilitas tersebut.
Para penyandang cacat atau disabilitas pun tidak serta-merta menutup mata akan perekonomian, karena hal tersebut bagian dari keberlangsungan hidup mereka. Agar dapat mencapai keseimbangan hidup bagi khalayak banyak, maka keseimbangan bagi mereka juga harus menjadi perhatian secara teoritis dan praktisnya.

\section{Akses Kesehatan}

Kebutuhan akan tubuh yang sehat merupakan kebutuhan asasi bagi setiap manusia, tanpa memandang status manusia tersebut. Tubuh yang sehat dan bebas dari segala penyakit adalah impian semua manusia. Akan tetapi, tidak demikian bagi kaum penyandang disabilitas. Di dalam tatanan masyarakat, seringkali kita ditemukan banyak penyandang disabilitas yang tidak mendapatkan pelayanan kesehatan. Hal tersebut terjadi karena banyak faktor seperti, sikap pengabaian dari keluarga, kondisi ekonomi dan tidak tersedianya pelayanan kesehatan bagi penyandang disabilitas di sarana dan prasarana bidang kesehatan.

Bagi penyandang disabilitas, kebutuhan kesehatan mereka mencakup pelayanan kesehatan umum dan pelayanan kesehatan khusus. Pelayanan kesehatan umum meliputi keluhan-keluhan umum (general) seperti sakit kepala, flu, ataupun penyakit-penyakit kronis lainnya. Sedangkan kebutuhan pelayanan kesehatan khusus antara lain kebutuhan yang berkaitan dengan disabilitasnya atau kecacatan yang ada pada dirinya. Misalnya, penyandang disabilitas spinal cord injury, membutuhkan pelayanan terapi fisik, membutuhkan alat bantu. Begitu pula yang tuna netra, membutuhkan perawatan kesehatan untuk merawat matanya, yang mengalami bibir sumbing membutuhkan biaya operasi bibir sumbing.

Penyandang disabilitas, harus memiliki biaya yang cukup banyak untuk membiayai pelayanan kesehatannya baik yang umum maupun yang khusus. Misalnya, sebuah keluarga mempunyai seorang anak yang mengalami bibir sumbing. Keluarga tersebut merencanakan untuk membawa anak tersebut 
mendapatkan pelayanan operasi bibir sumbing.

Mirisnya adalah adanya keterlambatan dalam mendapatkan pelayanan perawatan disabilitas sangat kompleks karena di dalamnya berimplikasi masalah ekonomi dan jarak. Kemiskinan menyebabkan orang tidak dapat pergi mendapatkan perawatan disabilitasnya. Jarak yang jauh menyebabkan biaya yang sangat tinggi yang sudah tentu sangat sulit dijangkau oleh mereka yang tidak memiliki dana yang cukup. Kita temukan fakta dimana banyak penyandang disabilitas yang tidak mendapatkan pelayanan terapi, operasi kecacatan (bibir sumbing dan kaki bengkok), alat-alat bantu disabilitas. The United Nations Departemen For International Development, Disability, Poverty and Development (DFID) mengatakan bahwa sebanyak lima puluh persen disabilitas dapat dicegah dan secara langsung berkaitan dengan lingkaran kemiskinan.

Berangkat dari hal tersebut, termaktub dalam Konvensi Hak-Hak penyandang Disabilitas Pasal 25 memberi penegasan terhadap setiap negara sebagai negara pihak konvesi harus;

\section{Menyediakan bagi penyandang} disabilitas dengan pelayanan dan program-program kesehatan yang layak, berkualitas, dan bebas biaya, sebagaimana disediakan bagi orang lain, termasuk di bidang kesehatan seksual dan reproduksi serta program-program kesehatan publik yang berdasarkan pada populasis.

2. Menyediakan pelayanan kesehatan yang dibutuhkan oleh orang-orang penyandang disabilitas karena disabilitas mereka, termasuk identifikasi di tahap awal intervensi yang diperlukan, serta pelayanan yang dirancang untuk meminimalisir dan mencegah disabilitas lebih lanjut, termasuk di antara anak-anak dan orang tua.
3. Menyediakan pelayanan kesehatan yang sedekat mungkin dengan masyarakat dimana orang-orang tersebut bertempat tinggal termasuk di daerah-daerah pedesaan.

4. Menyediakan profesionalis medis untuk memberikan perawatan kepada penyandang disabilitas dengan kualitas yang sama seperti pada orang lainnya, termasuk atas dasar persetujuan yang diberikan secara bebas dan diketahui secara menyeluruh, misalnya dengan meningkatkan kesadaran tentang hak asasi manusia, martabat manusia, otonomi dan penyebarluasan standarstandar etika pelayanan kesehatan publik dan privat.

5. Melarang diskriminasi terhadap penyandang disabilitas dalam ketentuang tentang asuransi kesehatan dan asuransi jiwa dimana asuransi semacam itu diperkenankan dalam hukum nasional, yang harus disediakan dengan cara yang adil dan layak.

6. Mencegah diskriminasi atas penyangkalan pemberian perawatan kesehatan atau pelayanan atau makan dan cairan atas dasar disabilitas.

\section{Akses Politik}

Pemenuhan hak politik bagi penyandang disabilitas. Hingga saat ini sangat terasa bahwa penyandang disabilitas belumlah secara maksimal dapat ikut serta dalam bidang politik dan pemerintahan di Negara Republik Indonesia ini. Padahal Undang-Undang Dasar 1945 sebagai konstitusi Negara Republik Indonesia juga telah mengamanatkan bahwa setiap warga negara memiliki kedudukan yang sama dalam hukum dan pemerintahan ${ }^{10}$. Kemudian, mengenai hak politik penyandang disabilitas diatur dalam Undang-Undang Nomor 8 Tahun 2016 tentang Penyandang Disabilitas dimana hak politik penyandang disabilitas meliputi ${ }^{11}$ :

a. Memilih dan dipilih dalam jabatan public,

\footnotetext{
${ }^{11}$ Pasal 13 UU No. 8 Tahun 2016 Tentang Penyandang Disabilitas
} 
b. Menyalurkan aspirasi politik baik tertulis maupun lisan,

c. Memilih partai politik dan/atau individu yang menjadi peserta dalam pemilihan umum,

d. Membentuk, menjadi anggota dan/atau pengurus organisasi masyarakat dan/atau partai politik,

e. Membentuk dan bergabung dalam organisasi penyandang disabilitas dan untuk mewakili Penyandang Disabilitas pada tingkat lokal, nasional, dan Internasional,

f. Berperan serta secara efektif dalam sistem pemilihan umum pada semua tahap dan/atau bagian penyelenggaraannya,

g. Memperoleh aksebilitas pada sarana dan prasarana penyelenggaraan pemilihan umum, pemilihan gubernur, bupati/walikota, dan pemilihan kepala desa atau nama lain,

h. Memperoleh pendidikan politik

Dari beberapa hal di atas, dalam pemenuhan akses politik seyogianya memberikan ruang terhadap penyandang disabilitas. Jika terdapat orang yang tidak bisa datang dalam agenda pemilihan umum, di sini pemerintah harus membuat tim khusus atau shadow teacher yang dapat masuk ke rumahrumah penduduk yang terindikasi mengalami disabilitas atau cacat guna terpenuhi hak politiknya.

\section{PENUTUP}

Pembangunan berkelanjutan tidak semata-mata hanya pada aspek ekonomi saja, melainkan harus masuk ke sumua aspek seperti, pendidikan, ekonomi, social, politik, dan lain sebagainya, yang pada hal ini khususnya bagi penyandang disabilitas.

Dalam sektor pendidikan khususnya para pnyandang cacat atau disabilitas seyogianya berorientasi masa depan dan memiliki sifat kontinuitas yang dimulai dari dukungan penuh terhadap mereka serta aksesibilitas penuh yang memudahkan mereka sehingga terciptanya sumber daya manusia yang produktif dan efektif, jadi tidak putus hanya di bidang pendidikan saja, melainkan dapat memperhatikan ke banyak sector seperti, pendidikan, ekonomi, kesehatan, dan politik.

$-000-$

\section{DAFTAR PUSTAKA}

Aan Komariah, Djam'an Satori, 201), Metode Penelitian Kualitatif, Bandung, Alfabeta.

Abidin, Zainal. 2014. Filsafat Manusia, Memahami Manusia Melalui Filsafat. Bandung: PT. Remaja Rosdakarya Offset.

Alfaris, M. Ramadhana. 2017. Dukungan Sosial dan Aksesbilitas Pendidikan Inklusi Di Perguruan Tinggi Berorientasi Masa Depan dan Kontinuitas. Prosiding Praktik Pendidikan Bagi Penyandang Disabilitas. Malang: PSLD UB

Baron, dkk. 2005. Psikologi Sosial Edisi Kesepuluh Jilid 2. Terj. Ratna Djuwita, dkk. Jakarta : Erlangga.

Cohen, Sheldon \& Syme, S. Leonard. 1985. Social Support and Health. Florida : Academic Press.

Hurlock, E. 2004. Psikologi Perkembangan. Jakarta : Erlangga Press

Sugiyono. 2007. Metode Penelitian Kuantitatif Kualitatif dan $R \& D$. Bandung: Alfabeta.

2012. Metode Penelitian Kuantitatif Kualitatif dan $R \& D$. Bandung: Alfabeta.

Sunarto, Kamanto. 2004. Pengantar Sosiologi (Edisi Revisi). Jakarta: Lembaga Penerbit FE Universitas Indonesia.

Supriyadi Widodo Eddyono. 2015. Aspekaspek Criminal Justice Bagi Penyandang Disabilitas. Jakarta: Institute for Criminal Justice Reform.

\section{Jurnal dan Makalah}

Indah Permata \& Binahayati. R. Pelaksanaan Sekolah Inklusi di Indonesia. Prosiding KS: Riset \& PKM. Volume 2

Maria Nurma. 2016. Perlindungan Hukum Dari Diskriminasi Bagi Penyandang 
Disabilitas Dalam Dunia Kerja.

Universitas Atma Jaya Yogyakarta

Mugi Riskiana Halalia, 2017 Pemenuhan Hak

Politik Penyandang Disabilitas Sesuai Dengan Undang-Undang Nomor 8 Tahun 2016 tentang Penyandang Disabilitas oleh Komisi Pemilihan Umum (KPU) Kota Yogyakarta. Jurnal Supremasi Hukum, Vol. 6, No. 2. Desember 2017.

Sri Jarmitia, dkk 2016. Hubungan Antara Dukungan Sosial Dengan Kepercayaan Diri Pada Penyandang Disabilitas Fisik Di Slb Kota Banda Aceh. Jurnal Psikoislamedia. Volume 1 April 2016.

Utomo, Aksesibilitas Penyandang Disabilitas Menempuh Pendidikan Tinggi. Prodi PLB FKIP UNLAM

\section{Sumber Hukum}

Undang-Undang Dasar 1945

UU RI No. 4 Tahun 1997

Undang-Undang RI No. 28 tahun 2002

Undang-Undang No 18 Tahun 2014

Undang-Undang No 8 Tahun 2016

Undang-Undang Nomor 36 Tahun 2009 tentang Kesehatan

Permendiknas Nomor 70 Tahun 2009

Sumber Media Massa

https://nasional.tempo.co/read/574350/diskri minasi-pendidikan-bagi-disabilitasmeningkat

https://nasional.tempo.co/read/892515/kasusbullying-mahasiswa-difabelgunadarma-bakal-disomasi

\section{Internet}

http://harsidisilvester.blogspot.com/2017/09/ pelayanankesehatan-bagipenyandang.html 
